\title{
Chromosomal Rearrangements In Lymphocytes Of Head and Neck Squamous Cell Carcinoma Treated With Chemotherapeutic Agents
}

\author{
B. DESAI ${ }^{1}$, P. GADHIA ${ }^{2, *}$ \\ ${ }^{1}$ C.K.Pithawalla Institute of Pharmaceutical Science \& Research, Surat, 395007, Gujarat, India; ${ }^{2}$ Dept. of Biosciences, Veer Narmad South Gujarat \\ University, Surat, Gujarat, India \\ *Correspondence: pankajkgadhia@gmail.com
}

Received October 22, 2011 / Accepted March 7, 2012

\begin{abstract}
Squamous cell carcinoma especially of oral cavity is one of the most prevalent diseases in the world. Chromosomal rearrangements are known to play important role in the pathogenesis of many diseases including cancer. In case of Head and Neck Squamous Cell Carcinoma, chromosomal changes are detectable at all stages of tumor development providing excellent opportunity for chromosomal prognosis and therapy. The present work aimed to study the frequency and pattern of chromosomal aberrations in human peripheral blood lymphocyte culture of freshly diagnosed Head and Neck squamous cell carcinoma patients. Further In vitro anticancer drugs (5-Fluorouracil $\{5-\mathrm{FU}\}$ and Cisplatin) effects were studied for clastogenicity. Results indicated significant impact of chemotherapeutic agents on the frequency of different types of chromosomal rearrangements.
\end{abstract}

Key words: chromosomal aberrations, head and neck squamous cell carcinoma (HNSCC), invitro chemotherapy, peripheral blood lymphocyte culture (PBLC)

Oral squamous cell carcinoma (OSCC) is a major cause of morbidity and mortality worldwide, accounting for more than 275,000 new cases and over 120,000 deaths every year [1]. It is already known that non-random chromosomal aberrations occur in all human cancer types including squamous cell carcinoma (SCC) of the head and neck (HNSCC) [2]. Further many reports suggested that chromosomal aberrations and accumulation of mutations in many genes encoding crucial proteins or oncoproteins that control cell growth and apoptosis may also induce neoplastic formation $[3,4,5]$. However in case of Head and Neck SCC, chromosomal aberrations are found to be a dominant genetic event in carcinogenesis and may play an important role in cancer progression [6].

In the present study, chromosomal rearrangements were observed in freshly diagnosed HNSCC patients who had not undergone any chemotherapeutic and/or radiation treatment. Further, peripheral blood lymphocytes of patients were exposed to anticancer drugs namely 5 - Fluorouracil $\{5-\mathrm{FU}\}$ and Cisplatin commonly used for oral cancer treatment.

5-FU is considered to be purely an S phase active chemotherapeutic agent [7] and also causes DNA damage, specifically double strand (and single-strand) breaks, during synthetic phase of cell cycle due to the misincorporation of FdUTP into DNA $[8,9]$. On the other hand, Cisplatin is a potent anti-tumor agent being cytotoxic to tumor cells via DNA-protein and DNA-DNA interstrand and intrastrand crosslinks [10]. The drug may also induce programmed cell death or apoptosis [11].

Therefore, it is important to improve the patient survival rate in HNSCC and it is essential to find more accurate prognostic markers, if any, such as chromosomal rearrangements with different end points.

\section{Materials and Methods}

Lymphocyte Culture.Lymphocyte cultures were set by method of Hungerford [12] with slight modifications [13]. Heparinized whole blood $(0.5 \mathrm{ml})$ was added to a mixture containing $5 \mathrm{ml}$ of culture medium RPMI 1640 and $0.1 \mathrm{ml}$ phytohemagglutinin (Lectin). Then the culture vials were kept in HERA cell ${ }^{150} \mathrm{CO}_{2}$ incubator for $71 \mathrm{hrs}$, at $37^{\circ} \mathrm{C}$ with $5 \% \mathrm{CO}_{2}$. Then $0.1 \mathrm{ml}$ demecolcine solution was added at last 2 hours of incubation period to arrest cells at metaphase. The cells were collected by centrifugation, resuspended in a prewarmed hypotonic solution (KCL, $0.075 \mathrm{M}$ ) for 20-25 minutes and fixed 
in chilled methanol/ acetic acid (3:1 v/v) solution (Carnoy's fixative). Then drops of cell suspension were allowed to fall from at least 2.5 feet height on pre chilled and chemically cleaned slides. These slides were air dried on a hot plate at 50-60 ${ }^{\circ} \mathrm{C}$. All slides were blind coded and labelled soon after assuring about well spread chromosome.

Experimental protocol.Total of 60 Peripheral Blood Lymphocyte cultures (PBLC) of oral squamous cell carcinoma patients (blood was collected from Lions Cancer Detection Centre, Surat) were studied along with 60 age and sex matched controls. Written consent of patients was obtained. All control and patients were divided in 8 groups (Table 1).

Group A1 and Group A2.Total 15 PBL cultures of healthy individuals (Group A1) and 15 that of freshly diagnosed HNSCC patients (Group A2) respectively without chemotherapy treatment.

Group B1 and Group B2.Total 15 PBL cultures of control (Group B1) and 15 that of HNSCC patients (Group B2) exposed to $30 \mathrm{ng} / 30 \mu \mathrm{l}$ of 5 -FU added after 24 hours of initiation of lymphocyte culture.

Group C1 and Group C2. Total 15 PBL cultures of healthy individuals (Group C1) and 15 that of HNSCC patients (Group C2) exposed to $15 \mathrm{ng} / 15 \mu \mathrm{l}$ Cisplatin added at 24 hours in lymphocyte culture.

Group D1 and Group D2. Total 15 PBL cultures of control (Group D1) and 15 that of HNSCC patients (Group D2) exposed to combination of 5-FU and Cisplatin drugs at the concentration of $30 \mathrm{ng} / 30 \mu \mathrm{l}$ and $15 \mathrm{ng} / 15 \mu \mathrm{l}$ respectively after 24 hours of initiation of culture.

Slides were prepared from all the cultures and scored. Results were analysed statistically using student $\mathrm{t}$-test with aid of Statistical Package of Social Sciences (SPSS) software. The significance level for chromosomal aberrations was considered at $\mathrm{p}$ value $<0.05$.

\section{Results}

The results show frequency of chromosomal aberrations observed after chemotherapeutic exposure to peripheral blood lymphocytes of HNSCC patients in comparison to controls (Table 1). We found significant increase in chromosomal aberrations of Head and Neck Squamous cell carcinoma patients in comparison to control without any chemotherapeutic exposure to their lymphocytes ( $\mathrm{P}$ value $<0.05$ ). While PBLs exposed to 5- FU added at 24 hours of initiation of culture also revealed similar results. It was interesting to note that no statistical significant difference was observed in frequency of chromosomal aberrations in patients exposed to Cisplatin alone as well as in combination of 5-FU and Cisplatin.

On the other hand, gaps were excluded from total chromosomal aberrations, 5-FU exposure showed significant increase in chromosomal aberrations in comparison to controls ( $\mathrm{P}$ value $<0.05)$.

In all study groups it was remarkable to note that PSC (Premature separation of centromere) was significantly higher as compared to that of controls (P value < 0.05).

Peripheral Blood Lymphocytes of HNSCC patients not exposed to any chemotherapeutic agents showed significant increase in ring, chromatid gap, chromatid break and endoreduplication as compared to controls (Figure -1). In addition, the frequency of hypo diploids was found to be significantly higher in HNSCC patients ( $\mathrm{P}$ value $<0.05$ ).

5-FU exposure to patients exhibited significant increase in chromosome gap, chromosome and chromatid breaks and telomeric associations as compared to healthy individuals ( $\mathrm{P}$ value $<0.05$ ). While Cisplatin exposure showed significant increase in dicentric chromosomes, ring and chromatid interchange (Figure -1). In addition, Cisplatin exposure also showed significant increase in hyper diploid metaphase configuration (Figure -1). Exposure to combined drugs (5-FU and Cisplatin) showed a significant increase in chromatid breaks and hypo diploids (P value $<0.05)$ as compared to controls.

Table 2 indicates frequency of chromosomal aberrations in Head and Neck SCC patients with and without treatment of chemotherapeutic agents. A higher significant increase in chromosomal aberrations (chromosome break, ring and chromatid gap) was found in patients exposed to 5- FU (P value

Table 1. Chromosomal aberrations in Head and Neck squamous cell carcinoma after various treatments of chemotherapeutic agents as compared to control.

\begin{tabular}{|c|c|c|c|c|c|c|c|c|c|c|c|c|c|c|}
\hline & B & G & D & $\mathbf{R}$ & B & G & Int & $\begin{array}{c}\text { Total } \\
\text { aberrations }\end{array}$ & $\begin{array}{c}\text { Total aberrations } \\
\text { excluding gaps }\end{array}$ & ER & TA & PSC & Hypo & Hyper \\
\hline & \multicolumn{14}{|c|}{ Without Chemotherapy (Based on Group A1 \& A2) } \\
\hline \multirow[t]{2}{*}{$P$ value } & 0.15 & 0.29 & 0.49 & $0.04^{*}$ & $0.04^{\star}$ & $0.02^{\star}$ & 0.08 & $0.03^{\star}$ & 0.30 & $0.008^{\star}$ & 0.47 & $0.02^{\star}$ & $0.02^{*}$ & 0.12 \\
\hline & \multicolumn{14}{|c|}{ 5-Fluorouracil (Based on Group B1 \& B2) } \\
\hline \multirow[t]{2}{*}{ P value } & $0.01^{\star}$ & $0.02^{*}$ & 0.08 & 0.36 & $0.006^{*}$ & 0.09 & 0 & $0.004^{*}$ & $0.03^{*}$ & 0.03 & $0.01^{*}$ & $0.01^{*}$ & 0.05 & 0.36 \\
\hline & \multicolumn{14}{|c|}{ Cisplatin (Based on Group C1 \& C2) } \\
\hline \multirow[t]{2}{*}{ P value } & 0.24 & 0.22 & $0.04^{*}$ & $0.04^{*}$ & 0.29 & 0.41 & $0.004^{*}$ & 0.08 & 0.05 & 0.36 & 0.09 & $0.01^{\star}$ & 0.17 & $0.03^{*}$ \\
\hline & \multicolumn{14}{|c|}{ 5-FU + Cisplatin (Based on Group D1 \& D2) } \\
\hline P value & 0.33 & 0.35 & 0.33 & 0.05 & $0.03^{*}$ & 0.25 & 0.21 & 0.22 & 0.42 & 0.33 & 0.16 & $0.0008^{*}$ & $0.0007^{*}$ & 0.35 \\
\hline
\end{tabular}

$\left(^{*}-\mathrm{P}\right.$ value $<0.05$ significantly different from control)

(B- Break, G- Gap, D- Dicentric, R-Ring, Int- Chromatid Interchange, ER- Endoreduplication, TA- Telomeric association, PSC- Premature separation of centromere, Hypo- Hypodiploid, Hyper- Hyperdiploid,) 

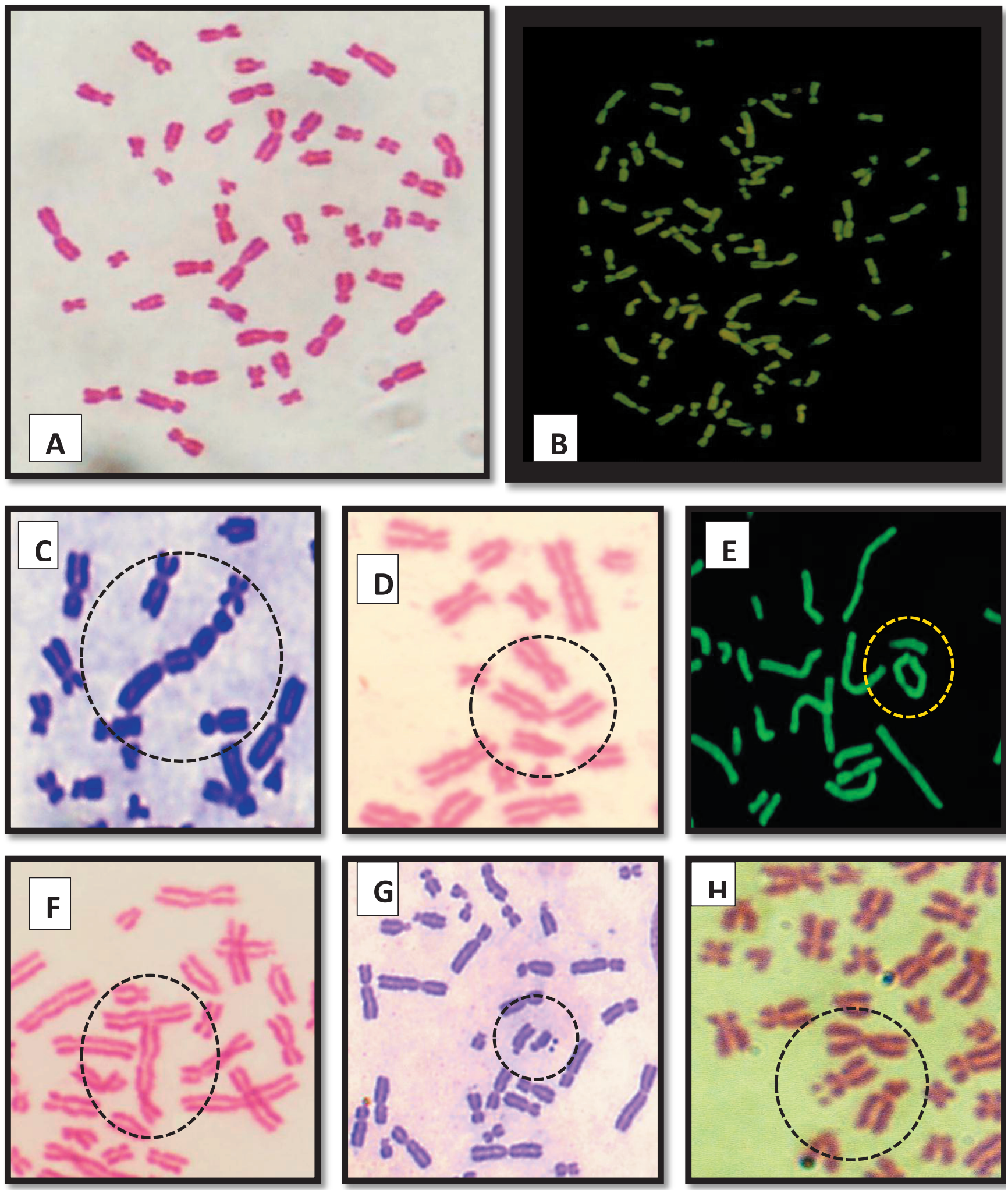

Figure1. Various types of chromosomal aberrations observed in oral SCC patients.

A) Normal metaphase plate. B) Hyper diploid metaphase plate. C) Telomeric association. D) Chromatid break. E) Open ring. F) Chromatid interchange.

G) Double minutes. H) Isochromatid gap 
$<0.05$ ). Further, it also induced hyper diploids (P value $<0.05$ ). However exposure to Cisplatin showed significant increase in chromatid gap, chromatid interchange, endoreduplication and hypo diploids except hyper diploid metaphases. (P value $<0.05)$.

Interestingly, when PBLs of HNSCC patients were exposed to combination of 5-FU and Cisplatin, it showed significantly higher increase in total aberrations values (including Dicentric, ring and chromatid gaps) as compared to those without chemotherapeutic exposure. Results of excluding gaps of total aberrations also showed similar results. $(\mathrm{P}$ value $<0.05)$

\section{Discussion}

Johanson [14] revealed that heritable acquired characteristics of neoplastic cells brought about by changes in the genetic material, does not imply that their neighbouring non neoplastic cells are without importance. Tumor cells face not only each other but also surrounding stromal tissue and the systemic antitumor response. This proposition supports even peripheral blood which is a non-neoplastic tissue can be used for cytogenetics.

Many previous studies have demonstrated that karyotypes of HNSCC and oral Squamous cell carcinoma consist of neartriploid chromosome numbers and contain various patterns of cytogenetic abnormality, including structural and numerical aberrations $[15,16,17]$. Chemotherapeutic drugs currently being used which may activate specific intracellular pathway(s) and induce apoptosis in target cells. Clinical applications combining different drugs may exhibit synergistic effects and reduce resistance and/or cytotoxicity [18].

We found significantly high number of hypo diploids chromosome plates in untreated HNSCC lymphocytes as compared to that of controls. Our results are in total agreement with those reported by Ravindran [19].

Similar frequency of hypo diploid chromosome plates was recorded in PBL exposure to combination of 5-FU and Cisplatin treated patients.
In addition, we have observed significantly high frequency of hyper diploids chromosome plates in PBLs of patients without any in vitro chemotherapeutic exposure.

Previously reported studies on chromosome number variability in Oral Squamous Cell Carcinoma ranges from 38 to 92 as reported by Ravindran [19] and 31 to 148 by Bazopoulou [20]. In our study we have found chromosome number ranging from 24 to 92 respectively. In addition, Christian et al. [21] has reported trisomy and monosomy of chromosome numbers 1, 7, 10, 17 and monosomy alone in chromosome number 9. However, in the present study we did not find involvement of any specific chromosome in case of trisomy and /or monosomy.

With regards to the loss of chromosome group namely A was reported in the literature, while the addition of groups $\mathrm{C}, \mathrm{D}, \mathrm{E}, \mathrm{F}$ and $\mathrm{G}$ of chromosomes were reported by Bazopoulou [20] and Ravindran [19]. In the present study we have found the loss of group A chromosome which is in a good agreement with earlier mentioned studies.

In present study, we have reported significant increase in total aberrations values after in vitro treatment of 5-FU to PBLs of HNSCC patients as compared to untreated PBLs of patients. On the other hand, the treatment of Cisplatin did not reveal any significant change. It is interesting to note that combination of the treatment with 5-FU and Cisplatin again showed significant increase in total aberrations values as compared to untreated PBLs of patients (Table 2).

This could suggest that the cancer cells with microsatellite instability are more sensitive to 5-FU, whereas more resistant to Cisplatin. In this context Reigetsu [22] described that depending on the dose given 5-FU acts via two different pathways. It causes G1-S phase cell cycle arrest in a dose of $1000 \mathrm{ng} / \mathrm{ml}$ that is same used by us $(30 \mathrm{ng} / 30 \mu \mathrm{l}) .5-\mathrm{FU}$ is thought to act via multiple pathways and that could be one of the reasons of its higher cytotoxicity to malignant cells.

Further it could be explained on the basis that HNSCC cells resistant to one drug may be susceptible to a combination of drugs due to availability of alternate apoptotic pathway activation [23]. It was well documented that high frequency of

Table 2. Chromosomal aberrations in Head and Neck SCC patients with and without treatment of chemotherapeutic agents.

\begin{tabular}{|c|c|c|c|c|c|c|c|c|c|c|c|c|c|c|}
\hline \multirow[b]{2}{*}{ Group } & \multicolumn{4}{|c|}{ Chromosome type aberrations } & \multicolumn{5}{|c|}{ Chromatid type aberrations } & \multicolumn{5}{|c|}{ Others } \\
\hline & B & G & D & $\mathbf{R}$ & B & G & Int & $\begin{array}{c}\text { Total } \\
\text { aberrations }\end{array}$ & $\begin{array}{c}\text { Total aberrations } \\
\text { excluding gap }\end{array}$ & ER & TA & PSC & Нypo & Hyper \\
\hline & & & & & & & & 5-Fluorourac & & & & & & \\
\hline \multirow[t]{2}{*}{$P$ value } & $0.006^{*}$ & 0.06 & 0.26 & $0.024^{\star}$ & 0.13 & $0.017^{\star}$ & 0.16 & $0.029^{\star}$ & 0.16 & 0.317 & 0.147 & 0.07 & 0.1593 & $0.01^{\star}$ \\
\hline & & & & & & & & Cisplatin & & & & & & \\
\hline$P$ value & & & & & & & & 5-FU + Cispla & & & & & & \\
\hline P value & 0.213 & 0.21 & $0.015^{*}$ & 0.006 & 0.5 & $0.014^{*}$ & 0.14 & $0.001^{\star}$ & $0.03^{\star}$ & $0.009^{*}$ & 0.444 & 0.5 & $0.0002^{\star}$ & 0.07 \\
\hline
\end{tabular}

(* - P value $<0.05$ significantly different from patients without chemotherapeutic exposure)

(B- Break, G- Gap, D- Dicentric, R-Ring, Int- Chromatid Interchange, ER- Endoreduplication, TA- Telomeric association, PSC- Premature separation of centromere, Hypo- Hypo diploid, Hyper- Hyper diploid ) 
numerical aberrations could be correlated with poor prognosis and higher DNA damage $[6,24]$.

Radiosensitivity of PBLs of cancer patients has already been reported [25] and it is now known that, chromosomal radiosensitivity of lymphocytes is a marker of genetic predisposition to head and neck cancer [26].

In the present study it was reported that the combination of chemotherapeutic drugs (5-FU and Cisplatin) is much more effective in comparison to individual drug in the treatment of HNSCC.

The in vitro action of chemotherapeutic agents may be different as compared to in vivo treatment used either individually or in combination resulting in the rearrangement of chromosomal aberrations. Head and neck squamous cell carcinoma patients predisposed to chromosomal rearrangements by anticancer drug treatment, may primarily promote the tumorigenesis.

Acknowledgements: Authors are highly thankful to Dr. Shrivastava, Director and Dr. RoshniJariwala of Lions cancer detection centre for providing blood samples. Special thanks to Dr. M. G. Saralai, Principal, C.K. Pithawalla Institute of Pharmaceutical Science \& Research for his kind support.

\section{References}

[1] PARKIN DM, BRAY F, FERLAY J, PISANI P Global cancer statistics, 2002. CA Cancer J Clin 2005; 55: 74-108. http: //dx.doi.org/10.3322/canjclin.55.2.74

[2] BODMER WF Cancer genetics. Br Med Bull 1994; 50: 517-526.

[3] REGEZI JA, JORDAN RC Oral cancer in the molecular age. J Calif Dent Assoc 2001; 29: 578-84.

[4] REGEZI JA, SCIUBBA JJ, JORDAN RCK Oral pathology. 4th ed. W.B. Saunders, 2003: Chapter 2: 23-74.

[5] SCULLY C, FIELD JK, TANZAWA H Genetic aberrations in oral or head and neck squamous cell carcinoma 2: chromosomal aberrations. Oral Oncol 2000; 36: 311-27. http: //dx.doi. org/10.1016/S1368-8375(00)00021-X

[6] HIROAKIS, NARIKAZU U, KEN-ICHIRO T, KUNIHIRO M, YOSHIO O et al. Prognostic utility of chromosomal instability detected by fluorescence in situ hybridization in fine-needle aspirates from oral squamous cell carcinomas. BMC Cancer 2010; 10: 182: 01-08.

[7] SHAH MA, SCHWARTZ GK Cell cycle-mediated drug resistance: An emerging concept in cancer therapy. Clin Cancer Res 2001; $7: 2168-2181$.

[8] CURTIN NJ, HARRIS AL, AHERNE GW Mechanism of cell death following thymidylate synthase inhibition: 2'-deoxyuridine-5'-triphosphate accumulation, DNA damage, and growth inhibition following exposure to CB3717 and dipyridamole. Cancer Res 1991; 51: 2346-2352.

[9] PETERS GJ, VAN TRIEST B, BACKUS HH, KUIPER CM, VAN DER WILT CL et al. Molecular downstream events and induction of thymidylate synthase in mutant and wild-type p53 colon cancer cell lines after treatment with 5-fluorour- acil and the thymidylate synthase inhibitor raltitrexed. Eur J Cancer 2000; 36: 916-924. http: //dx.doi.org/10.1016/S09598049(00)00026-5

[10] EASTMAN A The formation, isolation and characterization of DNA adducts produced by anticancer platinum complexes. Pharmacol. Ther 1987; 34: 155-166. http: //dx.doi. org/10.1016/0163-7258(87)90009-X

[11] EASTMAN A The mechanism of action of Cisplatin: From adducts to apoptosis, in Cisplatin. Chemistry and Biochemistry of a Leading Anticancer Drug. Bernhard Lippert, Editor, Wiley-VCH, Basel, Switzerland, 1999; 111-134.

[12] HUNGERFORD D A Leukocytes cultured from small inocula of whole blood and the preparation of chromosomes by treatment with hypotonic KCl. Stain. Technol 1965; 40: 333-338.

[13] GADHIA P K, SHAH N P, NAHATA S, PATEL S, PATEL $\mathrm{K}$ et al. Cytogenetic analysis of radiotherapeutic\& diagnostic workers occupationally exposed to radiation. Int J Hum Genet 2004; 4: 65-69.

[14] JOHANSON B, MERTENS F, MITELMAN F Primary vs. secondary neoplasia-associated chromosomal abnormalities-balanced rearrangement vs. genomic imbalances. Genes, Chromosomes \& Cancer 1986; 16: 155-163. http: //dx.doi. org/10.1002/(SICI)1098-2264(199607)16: 3<155: : AIDGCC1>3.0.CO; 2-Y

[15] GOLLIN SM Chromosomal alterations in squamous cell carcinomas of the head and neck: window to the biology of disease. Head Neck 2001; 23: 238-253. http: //dx.doi.org/10.1002/ 1097-0347(200103)23: 3<238: : AID-HED1025>3.0.CO; $\underline{2-\mathrm{H}}$

[16] JIN C, JIN Y, WENNERBERG J, AKERVALL J, DICTOR M et al. Karyotypic heterogeneity and clonal evolution in squamous cell carcinomas of the head and neck. Cancer Genet Cytogenet2002; 132: 85-96. http://dx.doi.org/10.1016/S01654608(01)00535-0

[17] RESHMI SC, GOLLIN SM Chromosomal instability in oral cancer cells. J Dent Res 2005; 84: 107-117. http: //dx.doi. org/10.1177/154405910508400203

[18] ITA M, OKAFUJI M, FUKUDA K, MITSUOKA K, HANAKITA $T$ et al. Concurrent chemo radiotherapy with new platinum compound nedaplatin in oral cancer. Oral Oncol 2003; 39: 144-9. http: //dx.doi.org/10.1016/S1368-8375(02)00035-0

[19] RAVINDRAN A, VIJAYAKUMAR T, SUDHA L, REMANI $\mathrm{P}$, VASUDEVAN D $\mathrm{M}$ et al. Chromosome abnormalities in squamous cell carcinoma of the human oral cavity Neoplasma 1990; 37: 191-197.

[20] BAZOPOULOU-KYRKANIDOU E, GARAS JI, ANGELOPOULOS AP, PANDIS N Karyotypic abnormalities of squamous cell carcinoma of the oral cavity. J Oral Pathol. 1983 Jun; 12: 167-76. http: //dx.doi.org/10.1111/j.1600-0714.1983. tb00330.x

[21] CHRISTIAN F, ANDREAS P, MARTIN F, HAGEN W, X. BOSCH Oral Leukoplakias Show Numerical Chromosomal Aberrations Detected by Fluorescence in Situ Hybridization. The Laryngoscope 1998; 108: 917-922. http: //dx.doi. org/10.1097/00005537-199806000-00023

[22] REIGETSU YOSHIKAWA, MASATO KUSUNOKI, HIDENORI YANAGI, MASAFUMI NODA, JUN-ICHI 
FURUYAMA et al. Dual Antitumor Effects of 5-Fluorouracil on the Cell Cycle in Colorectal Carcinoma Cells: A Novel Target Mechanism concept for Pharmacokinetic Modulating Chemotherapy. Cancer Res 2001; 61: 1029-1037.

[23] STEPHEN H, BALDEV S, GEORGE S Induction of apoptosis in oral cancer cells: Agents and mechanisms for potential therapy and prevention. Oral Oncology 2003; 01-13.

[24] XIN X, OLE PETTER F, MORTEN B Correlation of Numerical Aberrations of Chromosomes X and 11 and Poor Prognosis in Squamous Cell Carcinomas of the Head and Neck. (Reprinted) arch otolaryngol head neck surg 2006; 132: 511-515.
[25] SADAYUKI BAN, CHIKA KONOMI, MAYUMI IWAKAWA, SHIGERU YAMADA, TATSUYA OHNO et al. Radiosensitivity of peripheral blood lymphocytes obtained from patients with cancers of breast, head and neck or cervix as determined with a micronucleus assay. J.radiat. Res. 2004; 535-541.

[26] K DE RUYCK, V DE GELDER, M VAN EIJKEREN, T BOTERBERG, W DE NEVE et al. Chromosomal radiosensitivity in head and neck cancer patients: evidence for genetic predisposition? British Journal of Cancer 2008; 98: 1723 - 1728. http: //dx.doi.org/10.1038/sj.bjc.6604345 